\title{
Early Season Survey of Pea Viruses in Pakistan and the Detection of Two New Pathotypes of Pea Seedborne Mosaic Potyvirus
}

\author{
Akhtar Ali and J. W. Randles, Department of Crop Protection, University of Adelaide, Waite Campus, Glen Os- \\ mond, SA 5064, Australia
}

\begin{abstract}
Ali, A., and Randles, J. W. 1997. Early season survey of pea viruses in Pakistan and the detection of two new pathotypes of pea seedborne mosaic potyvirus. Plant Dis. 81:343-347.

Sixty-two commercial pea fields or experimental plots located in eight districts of the major pea-growing areas of North West Frontier Province (NWFP) of Pakistan were surveyed for pea viruses in the early winter growing season of 1995. Samples were analyzed by dotimmunobinding assay (DIBA) using antisera to 14 different viruses. Of the 713 plants sampled, 82 were positive for either bean yellow mosaic potyvirus, cucumber mosaic cucumovirus, or pea seedborne mosaic potyvirus (PSbMV), with an average incidence of 9.4, 0.57, and 1.5\%, respectively. PSbMV was also detected in 1 to $5 \%$ of dry seed from five of the 12 pea varieties tested and in 8 to $20 \%$ of seedlings raised from seed of three of these varieties. The infectivities of 12 PSbMV isolates found in the survey of pea varieties from Pakistan were compared using a standard range of pea differential genotypes, and the isolates were classified into four distinct pathotypes. Four isolates were classified as pathotype P-1 and two as P-4. The remainder did not fit into the existing PSbMV pathotype classification and were tentatively placed into two other groups named U-1 and U-2.
\end{abstract}

Additional keywords: virus resistance

Pea (Pisum sativum L.) is the fourth most important grain legume crop worldwide (10). Green pea production is 4.8 million tons grown on 0.76 million ha, and dry pea production is 16.3 million tons grown on 9.5 million ha $(10,21)$. In Pakistan, green pea is the second most important food legume crop after chickpea (Cicer arietinum L.), but production figures of 70,800 tons grown on an area of 141,400 ha (7) are well below the world average. Peas are grown in all provinces as a winter crop, but in the North West Frontier Province (NWFP), they are also grown as an autumn crop.

Epidemics of viruslike diseases are prevalent in winter-grown peas in Pakistan, but the causal viruses have not been identified. Thirty-five viruses have been reported to infect peas naturally or experimentally (11). Of these, pea seedborne mosaic potyvirus (PSbMV) is one of the most important because it can reach a high incidence through combined seed and aphid transmission $(12,14,17,19,23)$ and cause high yield losses $(5,6)$. It is distributed in seed through international commerce and germ plasm exchange and has been reported

Corresponding author: A. Ali

E-mail: aali@waite.adelaide.edu.au

Accepted for publication 17 January 1997.

Publication no. D-1997-0228-06R

(C) 1997 The American Phytopathological Society from more than 30 countries (21) since its discovery in 1966 (22). In Pakistan, a severe disease in lentil (Lens culinaris Medik.) was attributed to PSbMV in 1992 (2), but the virus was first reported in experimental pea crops in 1993 (9). Three pathotypes of PSbMV, P-1 and P-4 from peas and L-1 from lentil, were identified and characterized by their reactions on a specific range of pea genotypes (3).

This paper describes a limited survey for viruses in early winter grown pea crops in NWFP of Pakistan. In particular, it reports the detection of four pathotypes of PSbMV, two of which do not fit into the existing classification and thus represent previously undescribed pathotypes.

\section{MATERIALS AND METHODS}

Sources of seed, antisera, and viruses. Seeds of all indicator plant species were obtained from the University of Adelaide, Waite Campus collection. Pea varieties from Pakistan (Tables 1 and 2) were collected from seed markets, farms, and experimental stations during November and December 1995. Pathotype-specific (Table 3) pea differential genotypes (3) were provided by J. D. Fletcher, Crop and Food Research, New Zealand. Host group specific (Table 4) pea differential genotypes (13) were provided by A. D. McIntyre, Australian Temperate Field Crops Collection, Victorian Institute for Dry Land Agriculture. All antisera used were obtained from the Waite Campus collection except for bean leaf roll luteovirus (BLRV) an- tiserum, which was from the collection of K. Izadpanah, Shiraz University, Iran. Polyclonal PSbMV antiserum was prepared from the South Australian S6 isolate (16). Cultures of alfalfa mosaic alfamovirus (AMV), bean yellow mosaic potyvirus (BYMV), and cucumber mosaic cucumovirus (CMV) were obtained from the Waite Campus collection. BLRV was supplied by M. Schwinghamer, Department of Agriculture, NSW. The PSbMV-US and the PSbMV-S6 isolates (16) were used as representatives of pathotypes $\mathrm{P}-1$ and $\mathrm{P}-4$, respectively (4).

Survey area. Sixty-two commercial pea fields or experimental plots from 45 locations in eight districts of the major peagrowing areas of NWFP were surveyed for pea viruses during November and December 1995. Three of the districts, Abbottabad, Haripur, and Swat (Table 5), were in the hilly region, the remainder were on the plains.

Sampling. Leaf samples comprising two to three leaflets were collected from plants using a systematic random crop sampling procedure (8). Symptomatic plants observed during the survey were sampled further by taking flowers and pods containing green seed. Samples were placed separately in plastic bags, transported on ice to the laboratory, extracted, and applied to the membrane within $24 \mathrm{~h}$ of collection. The crops sampled varied in time of sowing, developmental stage, cultivar, and site. Samples were collected and tested serologically for 14 different viruses: AMV, BLRV, beet western yellows luteovirus (BWYV), BYMV, broad bean mottle bromovirus (BBMV), broad bean true mosaic comovirus (BBTMV), CMV, cowpea chlorotic mottle bromovirus (CCMV), lettuce mosaic potyvirus (LMV), pea enation mosaic enamovirus (PEMV), peanut mottle potyvirus (PMV), peanut stunt cucumovirus (PSV), PSbMV, and pea stem necrosis virus (PSNV). Species of both aphids and weeds within the pea field or adjacent to it were recorded, and some weeds were sampled. Samples that were serologically positive for virus were dried over calcium chloride for transfer to the Waite Campus.

Sample preparation. Leaf tissue samples of $0.5 \mathrm{~g}$ were placed in individual plastic bags $(75 \times 140 \mathrm{~mm})$ and extracted by crushing with 1 volume (wt/vol) of PBS (137 mM NaCl, $3 \mathrm{mM} \mathrm{KCL,} 8 \mathrm{mM}$ $\mathrm{Na}_{2} \mathrm{HPO}_{4}$, and $1 \mathrm{mM} \mathrm{KH} \mathrm{PO}_{4}, \mathrm{pH}$ 7.4). 
One hundred seeds of each variety (VIP, Climax, Dasana, Rondo, Peshawar Local-I, Peshawar Local-II, Swabi Local, Arkeel AP-1, Hazara Local, Mashang, Nauvana, and PF-400) were soaked overnight in 10 $\mathrm{ml}$ of PBS buffer before extracting individually as above. In addition, 40 seeds of each of the 12 varieties were germinated and grown in a glasshouse held at 20 to $25^{\circ} \mathrm{C}$. At 5 weeks after emergence, a $0.5-\mathrm{g}$ sample comprising leaflets from the youngest compound leaf of each seedling was extracted as above. All extracts were centrifuged at $10,000 \times g$ for $5 \mathrm{~min}$. Aliquots of $1 \mu \mathrm{l}$ were dotted onto nitrocellulose membrane (BA85, 0.45- $\mu \mathrm{m}$ pore diameter, Schleicher and Schuell, Dassel). The membrane was air-dried and either analyzed immediately or stored at $4^{\circ} \mathrm{C}$. Residual extracts of the seed samples were stored at $-20^{\circ} \mathrm{C}$ for 6 days before inoculation onto test host species. Positive controls comprising sap from AMV-, BLRV-, BYMV-, CMV-, or PSbMV-infected leaves were dotted onto membranes at dilutions of $1 / 1,1 / 10$, and $1 / 100$.

Dot-immunobinding assay (DIBA). The DIBA of Ligat et al. (16) was modified as follows and used as a routine assay. All the blocking and antibody solutions contained glucose and mannose at a concentration of $600 \mathrm{mM}$ each to avoid nonspecific binding of antibodies to plant lectins (16). Incubations were performed at room temperature with gentle agitation.
Membranes dotted with leaf samples were blocked by immersing in solution $\mathrm{L}$, whereas membranes dotted with seed samples were blocked in solution $S$ for $1 \mathrm{~h}$. Solution $\mathrm{L}$ was prepared by homogenizing healthy pea leaves (var. Dundale) in 9 volumes (wt/vol) of PBS. Solution $\mathrm{S}$ was prepared by soaking healthy pea seeds overnight in PBS, before grinding in 9 volumes (wt/vol) of the same buffer. Both extracts were clarified by centrifugation at $10,000 \times g$ for $5 \mathrm{~min}$ before use. Glucose $(600 \mathrm{mM})$, mannose $(600 \mathrm{mM})$, skim milk (2.6\%), and BSA (1\%) were tested for their effect on blocking. The blocking solution was removed, replaced with polyclonal antibody (diluted 1:2,000 in PBS), and incubated for $1 \mathrm{~h}$ with membranes. Membranes were washed three times in AP 7.5 (alkaline phosphatase buffer; $100 \mathrm{mM}$ Tris- $\mathrm{HCl}, \mathrm{pH} 7.5,100 \mathrm{mM} \mathrm{NaCl}, 2 \mathrm{mM}$ $\mathrm{MgCl}_{2}$, and $0.05 \%$ Triton $\mathrm{X}-100$ ) for 20 min each. Goat anti-rabbit IgG-alkaline phosphatase conjugate (Sigma Chemical Company, St. Louis, MO) was diluted 1:2,000 in PBS and incubated with the membranes for $1 \mathrm{~h}$. Membranes were washed as previously described, then once in AP 9.5 (alkaline phosphatase buffer; 100 $\mathrm{mM}$ Tris- $\mathrm{HCl}, \mathrm{pH} 9.5,100 \mathrm{mM} \mathrm{NaCl}$, and $5 \mathrm{mM} \mathrm{MgCl}_{2}$ ) before adding substrate. Membranes were incubated in AP 9.5 containing $0.33 \mathrm{mg}$ of nitro blue tetrazolium (NBT) per $\mathrm{ml}$ and $0.17 \mathrm{mg}$ of 5bromo-4-chloro-3-indolyl phosphate (BCIP)

Table 1. Detection of pea seedborne mosaic potyvirus by dot-immunobinding assay in seed and seedlings of Pakistani pea varieties

\begin{tabular}{lcccccc}
\hline & \multicolumn{2}{c}{ Seed } & & \multicolumn{3}{c}{ Seedlings } \\
\cline { 2 - 3 } \cline { 5 - 7 } Variety & Tested & Positive & & Tested & Symptomatic $^{\mathbf{a}}$ & Positive $^{\mathbf{a}}$ \\
\hline VIP & 100 & 1 & & 40 & 0 & 0 \\
Climax & 100 & 1 & & 32 & 0 & 0 \\
Dasana & 100 & 2 & & 23 & 2 & 3 \\
Rondo & 100 & 5 & & 25 & 3 & 5 \\
Peshawar Local-I & 100 & 2 & & 25 & 0 & 0 \\
Swabi Local & 100 & 0 & & 13 & 1 & 1 \\
\hline
\end{tabular}

${ }^{\text {a }}$ Five weeks after emergence. per $\mathrm{ml}$ (Sigma) in the dark for 5 to $15 \mathrm{~min}$. The reaction was stopped with $10 \mathrm{mM}$ Tris- $\mathrm{HCl}$, pH 7.5, containing 5 mM EDTA. Results were recorded visually by the intensity of color in comparison with a dilution series of positive controls.

Bioassay of PSbMV isolates and determination of pathotype. PSbMV isolates that tested positive by DIBA in field samples, seed extracts, or seedlings were transferred by mechanical inoculation (16) to Chenopodium amaranticolor Coste \& Reyn., C. quinoa L., and pea var. Dundale. Each selected isolate was also inoculated to three seedlings of the pathotype (3) and host-specific (13) pea differential genotypes (Tables 3 and 4).

Screening of pea varieties from Pakistan for susceptibility to PSbMV pathotypes P-1 and P-4. Pea varieties collected from Pakistan during the survey were tested for susceptibility to the P-1 (US isolate) and P-4 (S6 isolate) pathotypes of PSbMV. Four or five seedlings of each variety were mechanically inoculated with infected sap (diluted 1:2 [wt/vol] in $50 \mathrm{mM}$ sodium borate buffer, $\mathrm{pH}$ 8.1) of pathotype P-1 and P-4. Symptoms were recorded at 2 weeks after inoculation, and each plant was tested by DIBA. The plants were grown to maturity, and the seeds were also tested by DIBA for seed transmissibility of the two pathotypes.

\section{RESULTS}

Development of a reliable DIBA for diagnosis of pea viruses. High backgrounds typically obtained with DIBA of pea seed samples (16) were overcome by incubating membranes in blocking solution $\mathrm{S}$ containing both glucose and mannose. Skim milk $(2.6 \%)$ and BSA $(1 \%)$ had no additional effect on reducing background when added to the blocking solution and were ineffective when used alone as a blocking agent (data not shown). In our study, DIBA detected $1 \mathrm{ng}$ of purified PSbMV per $\mu$ l (Fig. 1A), and the dilution

Table 2. Susceptibility of pea varieties to infection by pea seedborne mosaic potyvirus pathotypes P-1 and P-4

\begin{tabular}{|c|c|c|c|c|c|c|c|c|}
\hline \multirow[b]{2}{*}{ Varieties } & \multicolumn{2}{|c|}{ Proportion symptomatic } & \multicolumn{2}{|c|}{$\begin{array}{c}\text { Proportion of seedlings } \\
\text { positive by DIBA }{ }^{\mathrm{a}}\end{array}$} & \multicolumn{2}{|c|}{$\begin{array}{c}\text { Proportion of seed }^{\mathbf{b}} \\
\text { positive by DIBA }\end{array}$} & \multicolumn{2}{|c|}{ Seed transmission $(\%)$} \\
\hline & P-1 & P-4 & P-1 & P-4 & P-1 & P-4 & P-1 & P-4 \\
\hline VIP & $0 / 5^{\mathrm{c}}$ & $0 / 5$ & $0 / 5$ & $0 / 5$ & & & & \\
\hline Climax & $0 / 5$ & $0 / 5$ & $0 / 5$ & $0 / 5$ & & & & \\
\hline Dasana & $4 / 4(1 r)$ & $0 / 4$ & $4 / 4$ & $0 / 4$ & $7 / 19$ & & 37 & \\
\hline Rondo & $1 / 4(\mathrm{lr})$ & $1 / 4(\mathrm{~m})$ & $2 / 4$ & $1 / 4$ & $1 / 8$ & $1 / 25$ & 13 & 4 \\
\hline Mashang & $4 / 4$ (lr) & $2 / 4(\mathrm{M})$ & $4 / 4$ & $2 / 4$ & $0 / 15$ & $0 / 8$ & 0 & 0 \\
\hline Nauvana & $4 / 4$ (lr) & $0 / 4$ & $4 / 4$ & $0 / 4$ & $10 / 18$ & & 56 & \\
\hline Arkeel Ap-1 & $2 / 4(\operatorname{lr})$ & $0 / 4$ & $4 / 4$ & $0 / 4$ & $8 / 17$ & & 47 & \\
\hline PF-400 & $4 / 5$ (lr) & $0 / 4$ & $4 / 5$ & $0 / 4$ & $4 / 8$ & & 50 & \\
\hline Peshawar Local-I & $2 / 3(\mathrm{lr})$ & $0 / 4$ & $2 / 3$ & $0 / 4$ & $5 / 27$ & & 19 & \\
\hline Peshawar Local-II & $1 / 4(\mathrm{lr})$ & $2 / 3(\mathrm{M})$ & $2 / 4$ & $2 / 3$ & $2 / 30$ & $4 / 25$ & 7 & 16 \\
\hline Hazara Local & $3 / 4$ (lr) & $0 / 4$ & $3 / 4$ & $0 / 4$ & $2 / 23$ & & 9 & \\
\hline Swabi Local & $0 / 3$ & $0 / 3$ & $0 / 3$ & $0 / 3$ & & & & \\
\hline
\end{tabular}

a Dot-immunobinding assay.

${ }^{\mathrm{b}}$ Seed collected from infected plants.

${ }^{\mathrm{c}}$ Symptom symbols: $\mathrm{lr}=$ leaf rolling $($ mild); $\mathrm{M}, \mathrm{m}=$ mosaic $($ severe, mild). Numerator $=$ number symptomatic or positive, denominator $=$ number observed or tested. 
endpoint of sap from infected plants was 1/4,096 (Fig. 1B). All the blocking and antibody solutions could be used for at least five sequential membrane incubations with no apparent loss in detection. Membranes probed with one virus antiserum and stored for 2 to 3 months at room temperature could be successfully reprobed with another virus antiserum. Groups of four to five membranes (100 squares per membrane) dotted with different samples were also successfully blocked and probed together with each antiserum.

Detection of BYMV, CMV, and PSbMV in surveyed crops. The results of the survey for viruses present in pea are shown in Table 5. Eighty-two samples were positive for at least one of the three viruses BYMV, CMV, and PSbMV. None of the remaining 11 viruses (AMV, BLRV, BWYV, BBMV, BBTMV, CCMV, LMV, PEMV, PMV, PSV, and PSNV) were detected in any of the samples tested. Of the three viruses, BYMV had the highest incidence, occurring in 67 samples at four sites, followed by PSbMV in 11 samples at five sites and CMV in four samples at two sites. All three viruses were detected in samples taken from plants at the preflowering, flowering, and postflowering stages, but no 2- to 3-week-old plants were virus positive. Weed species found were Amaranthus sp., Brassica spp., Chenopodium spp. (including $C$. amaranticolor), $C u$ cumis sativus L., Datura stramonium L., L. culinaris, Phaseolus lathyroides L.,
Spinacia oleracea L., and Vicia faba L. Of these, only $V$. faba was positive for BYMV. Pea aphids (Acyrthosiphon pisum Harris) were observed on BYMV- and PSbMV-infected plants in the hilly areas. Only one sample had a mixed infection and contained BYMV and PSbMV. A variety of symptoms was observed in the field, including severe mosaic, transient vein clearing, stunting, rosetting, and mild leaf rolling. Most of the plants showing mosaic and transient vein clearing were positive for BYMV. Of the 11 samples positive for PSbMV by DIBA, three showed mild leaf rolling, while eight showed stunting and apical rosetting.

Detection of PSbMV in seed and seedlings. Seeds from five of the 12 commercial and local varieties from Pakistan tested were infected with PSbMV (Table 1). The highest incidence was found in variety Rondo (5\%). Seedlings from three of the above 12 pea varieties were infected with PSbMV (Table 1). When observations were made on seedlings 1 week after emergence, one seedling of Dasana and Rondo varieties showed severe leaf rolling. These infected seedlings remained stunted with short internodes and few flowers up to maturity. After 5 weeks, the number of symptomatic seedlings increased to two for Dasana, three for Rondo, and one for Swabi Local; and all showed mild leaf rolling, reduction of the leaf lamina, and vein banding. When tested by DIBA, the number of positive seedlings was three for
Dasana and five for Rondo, indicating that symptomless infection occurred (Table 1). Seeds and seedlings of varieties Arkeel AP-1, Hazara Local, Mashang, Nauvana, Peshawar Local-II, and PF-400 were negative to PSbMV. All the varieties showed poor emergence except VIP, as shown in Table 1. None of the seeds or seedlings were positive for BYMV.

PSbMV isolates and their reaction on pea differential genotypes. Twelve isolates were selected for comparison, as shown in Tables 3 and 4. PSbMV isolate 1 was obtained from a seedling of the local variety from Swabi; isolates 2 and 3 were from Dasana seedlings; isolates 4 and 5 were from Rondo seedlings; isolates 6, 7, 9, and 10 were from DIBA-positive seed extracts of Rondo; and isolate 8 was from a positive seed extract of variety VIP. Isolates 11 and 12 were collected from field plants during the survey. All of these isolates produced necrotic local lesions on $C$. amaranticolor, chlorotic local lesions on C. quinoa, and systemic leaf rolling and mosaic in Dundale pea. However, none of the DIBA-positive seed extracts from Climax, Dasana, and Peshawar Local-I were infectious to the above indicators.

The isolates were classified into pathotypes by the reactions induced on the standard pathotype-specific pea differential genotypes (3). None of the isolates infected lines 193586 or 193835 (Table 3), which are reported to be resistant to PSbMV. Isolates $2,3,6,7$, and 10 were typical of

Table 3. Reactions of Pakistani pea seedborne mosaic potyvirus (PSbMV) isolates on pathotype-specific pea differential genotypes 2 weeks after mechanical inoculation

\begin{tabular}{|c|c|c|c|c|c|c|c|c|c|c|c|c|c|c|}
\hline \multirow{2}{*}{$\begin{array}{l}\text { Pathotype- } \\
\text { specific }^{\mathrm{a}} \\
\text { genotypes }\end{array}$} & \multirow[b]{2}{*}{$\mathbf{U S}^{\mathbf{b}}$} & \multirow[b]{2}{*}{$\mathbf{S 6} \mathbf{b}^{\mathbf{b}}$} & \multicolumn{12}{|c|}{ Pakistani PSbMV isolates } \\
\hline & & & 1 & 2 & 3 & 4 & 5 & 6 & 7 & 8 & 9 & 10 & 11 & 12 \\
\hline 193586 & $\mathrm{R}^{\mathrm{c}}$ & $\mathrm{R}$ & $\mathrm{R}$ & $\mathrm{R}$ & $\mathrm{R}$ & $\mathrm{R}$ & $\mathrm{R}$ & $\mathrm{R}$ & $\mathrm{R}$ & $\mathrm{R}$ & $\mathrm{R}$ & $\mathrm{R}$ & $\mathrm{R}$ & $\mathrm{R}$ \\
\hline 193835 & $\mathrm{R}$ & $\mathrm{R}$ & $\mathrm{R}$ & $\mathrm{R}$ & $\mathrm{R}$ & $\mathrm{R}$ & $\mathrm{R}$ & $\mathrm{R}$ & $\mathrm{R}$ & $\mathrm{R}$ & $\mathrm{R}$ & $\mathrm{R}$ & $\mathrm{R}$ & $\mathrm{R}$ \\
\hline 269774 & $\mathrm{R}$ & $\mathrm{S}$ & $\mathrm{R}$ & $\mathrm{R}$ & $\mathrm{R}$ & $\mathrm{R}$ & $\mathrm{R}$ & $\mathrm{R}$ & $\mathrm{R}$ & $\mathrm{S}(\mathrm{M})$ & $\mathrm{S}(\mathrm{M}+\mathrm{IC})$ & $\mathrm{R}$ & $\mathrm{R}$ & $\mathrm{S}(\mathrm{M})$ \\
\hline 347329 & $\mathrm{~S}$ & $\mathrm{R}$ & $\mathrm{R}$ & S (lr) & S (lr) & $\mathrm{R}$ & $\mathrm{R}$ & $\mathrm{S}(\mathrm{lr})$ & S (LR) & $\mathrm{R}$ & $\mathrm{S}(\mathrm{m}+\mathrm{lr})$ & $\mathrm{S}(\mathrm{lr})$ & $\mathrm{R}$ & $\mathrm{R}$ \\
\hline 347422 & $S$ & $\mathrm{R}$ & $\mathrm{S}(\mathrm{lr})$ & S (lr) & S (lr) & S (lr) & S (lr) & $\mathrm{S}(\mathrm{lr})$ & $\mathrm{S}(\mathrm{lr})$ & $\mathrm{R}$ & $\mathrm{R}$ & $\mathrm{S}(\mathrm{lr})$ & $\mathrm{S}(\mathrm{lr})$ & $\mathrm{R}$ \\
\hline $\begin{array}{l}\text { Pathotype } \\
\text { grouping }\end{array}$ & $\mathrm{P}-1$ & $\mathrm{P}-4$ & $\mathrm{U}-1$ & $\mathrm{P}-1$ & $\mathrm{P}-1$ & $\mathrm{U}-1$ & $\mathrm{U}-1$ & $\mathrm{P}-1$ & $\mathrm{P}-1$ & $\mathrm{P}-4$ & $\mathrm{U}-2$ & $\mathrm{P}-1$ & $\mathrm{U}-1$ & P-4 \\
\hline
\end{tabular}

a Alconero et al. (1986).

b Ligat et al. (1991).

${ }^{\mathrm{c}}$ Symptom symbols: LR, $\mathrm{lr}=$ leaf roll (severe, mild); M, m = mosaic (severe, mild); IC = interveinal chlorosis; $\mathrm{R}=$ resistant as indicated by absence of symptoms and negative dot-immunobinding assay; $\mathrm{S}=$ susceptible.

Table 4. Reactions of Pakistani pea seedborne mosaic potyvirus (PSbMV) isolates on host-specific pea differential genotypes 2 weeks after mechanical inoculation

\begin{tabular}{|c|c|c|c|c|c|c|c|c|c|c|c|c|c|c|c|}
\hline \multirow{2}{*}{$\begin{array}{l}\text { Host } \\
\text { group }\end{array}$} & \multirow{2}{*}{$\begin{array}{l}\text { Host-specific } \\
\text { genotypes }^{\mathrm{a}}\end{array}$} & \multirow[b]{2}{*}{$\mathbf{U S}^{\mathbf{b}}$} & \multirow[b]{2}{*}{$\mathbf{S 6}^{\mathbf{b}}$} & \multicolumn{12}{|c|}{ Pakistani PSbMV isolates } \\
\hline & & & & 1 & 2 & 3 & 4 & 5 & 6 & 7 & 8 & 9 & 10 & 11 & 12 \\
\hline I & 272146 & $\mathrm{~N} !^{\mathrm{c}}$ & $\mathrm{N} !$ & $\mathrm{N} !$ & $\mathrm{N} !$ & $\mathrm{N} !$ & $\mathrm{N} !$ & $\mathrm{N} !$ & $\mathrm{N} !$ & $\mathrm{N} !$ & $\mathrm{N} !$ & $\mathrm{N} !$ & $\mathrm{N} !$ & $\mathrm{N} !$ & $\mathrm{N} !$ \\
\hline III & 269804 & $\operatorname{lr}$ & M & LR & LR & $1 \mathrm{r}$ & LR & $\operatorname{lr}$ & $\operatorname{lr}$ & LR & $\mathrm{M}+\mathrm{lr}$ & M & LR & LR & $\mathrm{M}+\mathrm{VC}$ \\
\hline III & 272171 & I & M & lr & lr & $\mathrm{lr}$ & VB & $\operatorname{lr}$ & $\operatorname{lr}$ & $\operatorname{lr}$ & $\mathrm{M}+\mathrm{lr}$ & M & lr & LR & M \\
\hline IV & 269777 & NT & NT & I & I & I & I & I & I & I & I & I & I & I & I \\
\hline V & 269774 & I & M & I & I & I & I & I & I & I & M & $\mathrm{M}+\mathrm{IC}$ & I & I & M \\
\hline
\end{tabular}

a Hampton et al. (1981).

${ }^{b}$ Ligat et al. (1991).

${ }^{c}$ Symptom symbols: N! = rapid whole plant necrosis and death; LR, $1 \mathrm{r}=$ leaf roll (severe, mild); $\mathrm{M}=$ severe mosaic; VB = vein banding and leaf size reduction; $\mathrm{VC}=$ vein clearing; $\mathrm{IC}=$ interveinal chlorosis; $\mathrm{NT}=$ not tested; $\mathrm{I}=$ immune as indicated by absence of symptoms and negative dotimmunobinding assay. 
pathotype $\mathrm{P}-1$, as shown by their ability to infect lines 347329 and 347422 . Isolates 8 and 12 were typical of pathotype P-4 by infecting only line 269774 (3). Isolates 1, 4,5 , and 11 were not typical of either P-1 or P-4 due to their inability to infect lines 347329 and 269774 and were classified as unknown 1 (U-1). Isolate 9 differed from all of the other isolates, in infecting both named unknown 2 (U-2).

In addition, the host group specific pea differential genotypes (13) were also used to distinguish the 12 Pakistani PSbMV isolates. All isolates (Table 4) uniformly caused rapid whole necrosis of line 272146 (host group I), confirming their identity as PSbMV. None of the isolates infected line 269777 (host group IV), which was previously reported to be susceptible to PSbMV (13).

Screening of pea varieties for resistance to the P-1 and P-4 pathotypes of PSbMV. Of the 12 pea varieties from Pakistan, nine were susceptible to either pathotype P-1 or P-4 (Table 2). The variethe $\mathrm{P}-1$ and $\mathrm{P}-4$ resistant lines. This was

ties VIP, Climax, and Swabi local were not susceptible to either pathotype, as shown by absence of symptoms and negative reactions by both DIBA and indexing on $C$. amaranticolor. Pathotype $\mathrm{P}-1$ produced typical mild leaf rolling in all nine varieties that were infected at 2 weeks after inoculation, while P-4 produced mild to severe mosaic and stunting in the three varieties it infected at only 1 week after inoculation. In susceptible varieties, the seed transmission of P-1 ranged from 0 to $55.5 \%$ and from 0 to $16 \%$ for P-4. Examples of symptomless infection were obtained for the varieties Rondo, Arkeel Ap-1, and Peshawar Local-II (Table 2), as shown by testing with DIBA.

\section{DISCUSSION}

DIBA has about the same sensitivity as enzyme-linked immunosorbent assay (ELISA) in microtiter plates (16), but it has the additional advantages of simplicity, speed, and economy. Moreover, prepared membranes can be stored, sent by mail, and reprobed with different antisera. DIBA

Table 5. Incidence of viruses in pea crops in North West Frontier Province of Pakistan as determined by dot immunobinding assay

\begin{tabular}{lccccc}
\hline & & & \multicolumn{3}{c}{ Plants positive $^{\mathbf{a}}$} \\
\cline { 5 - 6 } District & Fields & Samples & BYMV & CMV & PSbMV \\
\hline Abbottabad & 1 & 18 & 0 & 0 & 0 \\
Haripur & 14 & 184 & 62 & 0 & 2 \\
Swat & 6 & 57 & 1 & 0 & 4 \\
Peshawar & 22 & 240 & 2 & 2 & 2 \\
Charsadda & 1 & 11 & 0 & 0 & 0 \\
Swabi & 9 & 112 & 0 & 2 & 2 \\
Mardan & 5 & 50 & 2 & 0 & 0 \\
Malakand & 4 & 41 & 0 & 0 & 1 \\
$\quad$ Agency & & & & & \\
Total & 62 & 713 & $67(9.4 \%)$ & $4(0.57 \%)$ & $11(1.5 \%)$ \\
\hline
\end{tabular}

${ }^{\mathrm{a}} \mathrm{BYMV}=$ bean yellow mosaic potyvirus, $\mathrm{CMV}=$ cucumber mosaic cucumovirus, $\mathrm{PSbMV}=$ pea seedborne mosaic potyvirus.
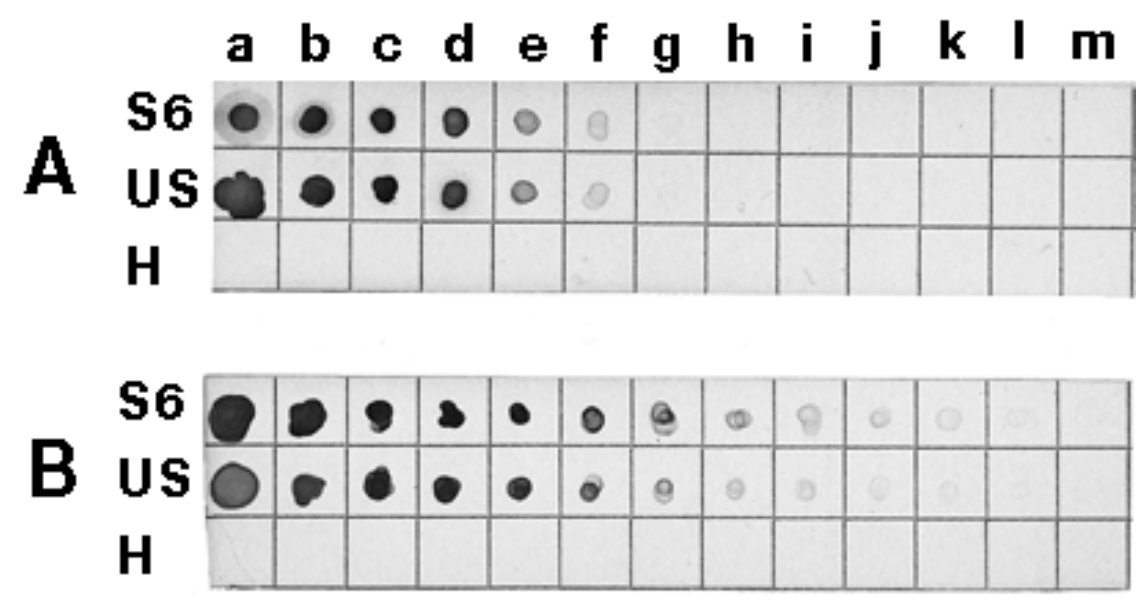

Fig. 1. (A) Dot-immunobinding assay detection of dilution endpoint of 1- $\mu 1$ aliquots of purified pea seedborne mosaic potyvirus (PSbMV)-S6 and -US isolates: $\mathrm{a}=1.2 \mu \mathrm{g}, \mathrm{b}=600 \mathrm{ng}, \mathrm{c}=300 \mathrm{ng}, \mathrm{d}=$ $100 \mathrm{ng}, \mathrm{e}=10 \mathrm{ng}, \mathrm{f}=1 \mathrm{ng}, \mathrm{g}=100 \mathrm{pg}, \mathrm{h}=10 \mathrm{pg}, \mathrm{i}=1 \mathrm{pg}, \mathrm{j}=100 \mathrm{fg}, \mathrm{k}=10 \mathrm{fg}, 1=1 \mathrm{fg}$. (B) Dilution endpoint of $1-\mu \mathrm{l}$ aliquots from infected sap of PSbMV-S6 and -US isolates ranging from $1 / 2$ to $1 / 8,192$ in a twofold dilution series. Row $\mathrm{H}$ indicates a twofold dilution series of sap from healthy pea. of pea seed is sometimes affected by high backgrounds (16), but we have been able to overcome this by further modifying DIBA for pea virus diagnosis in field plants and for detecting PSbMV in dry seed and germinated seedlings. The test gave consistent results with known positive samples of five viruses, indicating that it can probably be used for the routine indexing of pea viruses merely by varying the test antiserum in the procedure.

This survey was the first done for pea viruses in Pakistan and showed that natural infection with BYMV, CMV, and PSbMV occurred in the field. The survey results indicated that of these three viruses, PSbMV was the most widespread, occurring in five of the eight districts surveyed. The incidence of PSbMV in sampled crops ranged from 0 to $7 \%$, varying with respect to variety, seed source, and locality, and possibly with migratory aphid activity. The incidence of PSbMV in dry seed (0 to 5\%) was similar to that detected for field samples, suggesting that there had been little secondary spread of PSbMV up to the time of the survey (early winter). The absence of infection in sampled weeds (data not shown) also supports the view that they were not a source of virus, nor had PSbMV spread into them. Seed is therefore considered to be the main reservoir of PSbMV for survival between seasons.

Some of the plants showing viruslike symptoms failed to react with any of the virus antisera tested. These plants may be infected with viruses other than those tested for in this study or may have been exposed to other pathogens or environmental stresses leading to the production of viruslike symptoms. In the Abbottabad and Charsadda (Table 5) districts, where no virus infection was found, sample size would have been too small to detect infection levels below $10 \%$.

The incidence of PSbMV in dry seed from the five virus-positive varieties was 1 to $5 \%$ (Table 1) and was similar to the incidence of virus (0 to $4.3 \%)$ on the basis of symptoms in 1-week-old glasshouse seedlings raised from the same varieties. However, at 5 weeks postemergence, the percentage of plants infected with PSbMV was determined to be between 0 and $12 \%$ by symptoms and between 0 and $20 \%$ by DIBA. This increase in PSbMV incidence in young plants with time may be explained by delayed movement of PSbMV from infected embryos (15). This implies that seed transmission should be evaluated on 5-week-old plants rather than on seed or young seedlings. The observed differences between seed and seedling levels of infection are presumably due to the different rates of infection of the testa and embryo (20).

PSbMV isolates were grouped into the existing pathotype classification (3) by their ability to infect the range of standard pea differential genotypes. Isolates that did 
not fit into the existing classification and were therefore tentatively placed in groups U-1 and U-2 could possibly be defined as pathotypes P-5 and P-6, but further characterization of these is needed to define their biological properties. On the hostspecific genotypes, symptom variation was observed among the isolates, indicating that there is marked biological variability among isolates within the same pathotype.

In the pea varietal screening, the varieties VIP, Climax, and Swabi Local remained uninfected after mechanical inoculation by either the P-1 or P-4 pathotypes. However, VIP and Swabi Local were not immune to PSbMV because they yielded isolate $8(\mathrm{P}-4)$ and isolate 1 (U-1), respectively. The DIBA-positive seed extract from Climax was not classified because it did not infect indicator hosts. The virus in this variety may have been limited to the testa and lost infectivity during seed maturation, whereas in the other varieties, PSbMV probably infected the embryo and would therefore have been transmissible to the next generation. Further resistance testing should include transmission of P-1 and P-4 by aphids (1). It is also possible that isolates $1(\mathrm{U}-1)$ and $8(\mathrm{P}-4)$ are biologically different from the $\mathrm{P}-1$ and $\mathrm{P}-4$ isolates of Ligat et al. (16) and are able to overcome the resistance of these varieties. Further research is needed to compare these PSbMV isolates at the molecular level.

It is interesting to speculate that this wide variation among the PSbMV isolates from Pakistan is related to the long association of Pisum with this geographical region of the world (18). Perhaps the center of diversity of the crop can be correlated with high diversity in a seedborne virus such as PSbMV.

\section{ACKNOWLEDGMENTS}

We thank Professor Sher Hassan, Department of Plant Pathology, NWFP Agricultural
University, Pakistan, for the provision of laboratory and glasshouse facilities, and R. A. J. Hodgson, Department of Crop Protection, University of Adelaide, Australia, for critical review of the manuscript. We also thank the Australian Agency for International Aid (AusAID) for financial support of this project.

\section{LITERATURE CITED}

1. Aapola, A. A., Knesek, J. E., and Mink, G. I. 1974. The influence of inoculation procedure on the host range of pea seed-borne mosaic virus. Phytopathology 64:1003-1006.

2. Aftab, M., Iqbal, S. M., and Rauf, C. A. 1992. Effect of lentil strain of pea seed-borne mosaic virus on lentil. LENS Newsl. 19:51-53.

3. Alconero, R., Provvidenti, R., and Gonsalves, D. 1986. Three pea seedborne mosaic virus pathotypes from pea and lentil germ plasm. Plant Dis. 70:783-786.

4. Ali, A., and Randles, J. W. 1995. Some characteristics of a pathotype 4 isolate of pea seed-borne mosaic virus from South Australia. (Abstr.) Bienn. Australas. Plant Pathol. Soc. Conf., 10th, Christchurch, New Zealand.

5. Anonymous. 1985. Diseases of legumes. Pages 123-124 in: Rothamsted Experimental Station Report for 1985.

6. Anonymous. 1991. ICARDA (International Centre for Agricultural Research in the Dry Areas) Annu. Rep. pp. 29-30.

7. Anonymous. 1994. Agricultural statistics of Pakistan (1991-92). Government of Pakistan, Ministry of Food, Agriculture and Co-operation. Food and Agriculture Division, Economic Wing, Islamabad.

8. Barnett, O. W. 1986. Surveys for plant viruses: Design and considerations. Pages 147189 in: Plant Virus Epidemics, Monitoring, Modelling and Predicting Outbreaks. G. D. McLean, R. G. Garrett, and W. G. Ruesink, eds. Academic Press, Sydney.

9. Bashir, M., Khalid, S., Asif, M., and Banaras, M. 1993. First report of pea seed-borne mosaic virus in Pakistan. (Abstr.) International Working Group on Legume Viruses. p. 25.

10. Davies, D. R. 1993. The pea crop. Pages 1-12 in: Pea Genetics, Molecular Biology and Biotechnology. R. Casey and D. R. Davies, eds. John Innes Institute, Norwich.

11. Hagedorn, D. J., ed. 1984. Diseases caused by viruses. Pages 31-37 in: Compendium of Pea Diseases. American Phytopathology Society, St. Paul, MN.
12. Hampton, R. O., and Mink, G. I. 1975. Pea seed-borne mosaic virus. No. 146. Descriptions of Plant Viruses. Commonw. Mycol. Inst./Assoc. Appl. Biol., Kew, England.

13. Hampton, R. O., Mink, G. I., Bos, L., Inouye, T., Musil, M., and Hagedorn, D. J. 1981. Host differentiation and serological homology of pea seed-borne mosaic virus isolates. Neth. J. Plant Pathol. 87:1-10.

14. Hampton, R. O., and Muehlbauer, F. J. 1977. Seed transmission of pea seed-borne mosaic virus in lentils. Plant Dis. Rep. 61:235-238.

15. Khetarpal, R. K., and Maury, Y. 1990. Seed transmission of pea seed-borne mosaic virus in peas: Early and late expression of the virus in the progeny. J. Phytopathol. 129: 265-270.

16. Ligat, J. S., Cartwright, D., and Randles, J. W. 1991. Comparison of some pea seed-borne mosaic virus isolates and their detection by dot-immunobinding assay. Aust. J. Agric Res. 42:441-451.

17. Ligat, J. S., and Randles, J. W. 1993. An eclipse of pea seed-borne mosaic virus (PSbMV) in vegetative tissue of pea following repeated transmission through seed. Ann. Appl. Biol. 122:39-47.

18. Makasheva, R. K. 1983. Economic importance. Page 67 in: The Pea. Kolos Publishers, New Delhi.

19. Makkouk, K. M., Kumari, S. G., and Shehadeh, A. 1992. Seed transmission of pea seed-borne mosaic virus in Lathyrus and Vicia forage legume species. J. Plant Dis. Prot. 99:561-563.

20. Masmoudi, K., Suhas, M., Khetarpal, R. K., and Maury, Y. 1994. Specific serological detection of the transmissible virus in pea seed infected by pea seed-borne mosaic virus. Phytopathology 84:756-760.

21. Maury, Y., and Khetarpal, R. K. 1992. Pea seed-borne mosaic virus. Pages 74-92 in: Plant Disease of International Importance: Diseases of Vegetables and Oil Seed Crops. Vol II. H. S. Chaube, U. S. Singh, A. N. Mukhopadhyay, and J. Kumar, eds. Prentice Hall, Inc., Englewood Cliffs, NJ

22. Musil, M. 1966. Uber das vorkommen des Blattrollens der Erbse in der Slowakei (Vorrlaufige mitteilung). Biologia (Bratislava) 21:133-138.

23. Musil, M. 1980. Seed transmission of pea leaf rolling mosaic virus. Sameniibertragbarkeit Blattrollmosaik Virus Erbse 184:345-352. 